\title{
13
}

\section{Rapan agroecology and population estimates}

\author{
Jacob Bartruff \\ Department of Geography, University of Oregon, Eugene, USA, jbartruf@uoregon.edu \\ Douglas J. Kennett \\ Department of Anthropology, The Pennsylvania State University \\ Bruce Winterhalder \\ Department of Anthropology, University of California, Davis
}

\section{Introduction}

Colocasia taro (C. esculenta) grown in pondfield irrigation systems is the staple of Rapa's subsistence economy. Pondfield irrigation systems are well known in Oceania. Their development usually coincides with the prehistoric expansion of island populations and the associated need to increase crop yields from limited amounts of land (e.g. with intensification, Kirch 2000:317). The primary goal of this type of irrigation system is to create the most favourable growing conditions for Colocasia taro, pools of slow-moving water $2.5 \mathrm{~cm}$ to $5 \mathrm{~cm}$ deep. This involves the construction of artificial terraces, berms and irrigation canals that require a significant investment of time and labour for a pay-off of increased crop yields in the future. Augmentation of the land increases its value and one of the social manifestations of this investment is greater territoriality (Dyson-Hudson and Smith 1978). Hereditary ownership and the need to defend these territories from interested neighbours often develop within this context.

Colocasia taro is not native to Rapa, but was introduced by the early colonists of the island, along with several other commensal species. Wild variants of this plant can be found throughout the Indo-Pacific region from east India to Formosa and south into the Sahul region (Cable 1984). Wild-taro-starch residue identified on stone tools from the Solomon Islands extends its use back to 28,000 years ago (Loy et al. 1992). The traditional view is that domesticated taro was introduced to New Guinea by intrusive Austronesian populations from island Southeast Asia (Bellwood 1975), but recent evidence points to the possibility of an independent domestication 9000 years ago (Golson 1990; Yen 1991). Colocasia taro appears in west Polynesia during the late Lapita Period (ca. $3000 \mathrm{BP}$ ) and was carried in canoes to more remote islands of east 
Polynesia, including Rapa, starting 1500 to 2200 years later (Kennett et al. 2006a).

Oral traditions suggest that Colocasia taro was the staple food on Rapa from the time of initial settlement (Hanson 1970; Stokes n.d.), now estimated to be between ca. AD 1100 and 1200 (Kennett et al. 2006b; Chapter 11). Pollen from well-dated stratified lowland sediments indicates its use by at least AD 1200 (Chapter 10). Pondfields dot the alluvial lowlands of Rapa today. Remnant dry stonewall terrace features covering many of the alluvial valley bottoms are indicative of much greater former extent of these agricultural systems. Many of the abandoned or fallow terrace systems remain waterlogged and are now dominated by introduced agricultural grasses (e.g. Paspalum subjugatum), sedges (e.g. Carex spp.), rushes (e.g. Schoenoplectus subulatus subsp. subulatus) and adventitious herbs (e.g. Commelina diffusa). These terraces are visible in 1 $\mathrm{m}$ resolution IKONOS satellite imagery, and the purpose of this paper is to define the former extent of taro production based on this imagery. We also explore prehistoric Rapan population levels based on calculations of potential agricultural yield and maximum sustainable population sizes under different regimes of diverted production.

\section{Colocasia taro production on Rapa}

Active and remnant pondfield terraces are visible in all the lowland valleys of Rapa (Figure 13.1). This irrigation method is one of the four types of true irrigation (e.g. diversion of water to fields) in the Pacific, as defined by Spriggs $(1981,1988)$. Ferdon (1965) conducted a preliminary survey of these terraces and found that almost all of the alluvial valley bottoms on the island were terraced at one time or another, including the land beneath the modern town of Ha'urei. Some of these terraces are still in use today but they represent only a small proportion of the available arable land once under production.

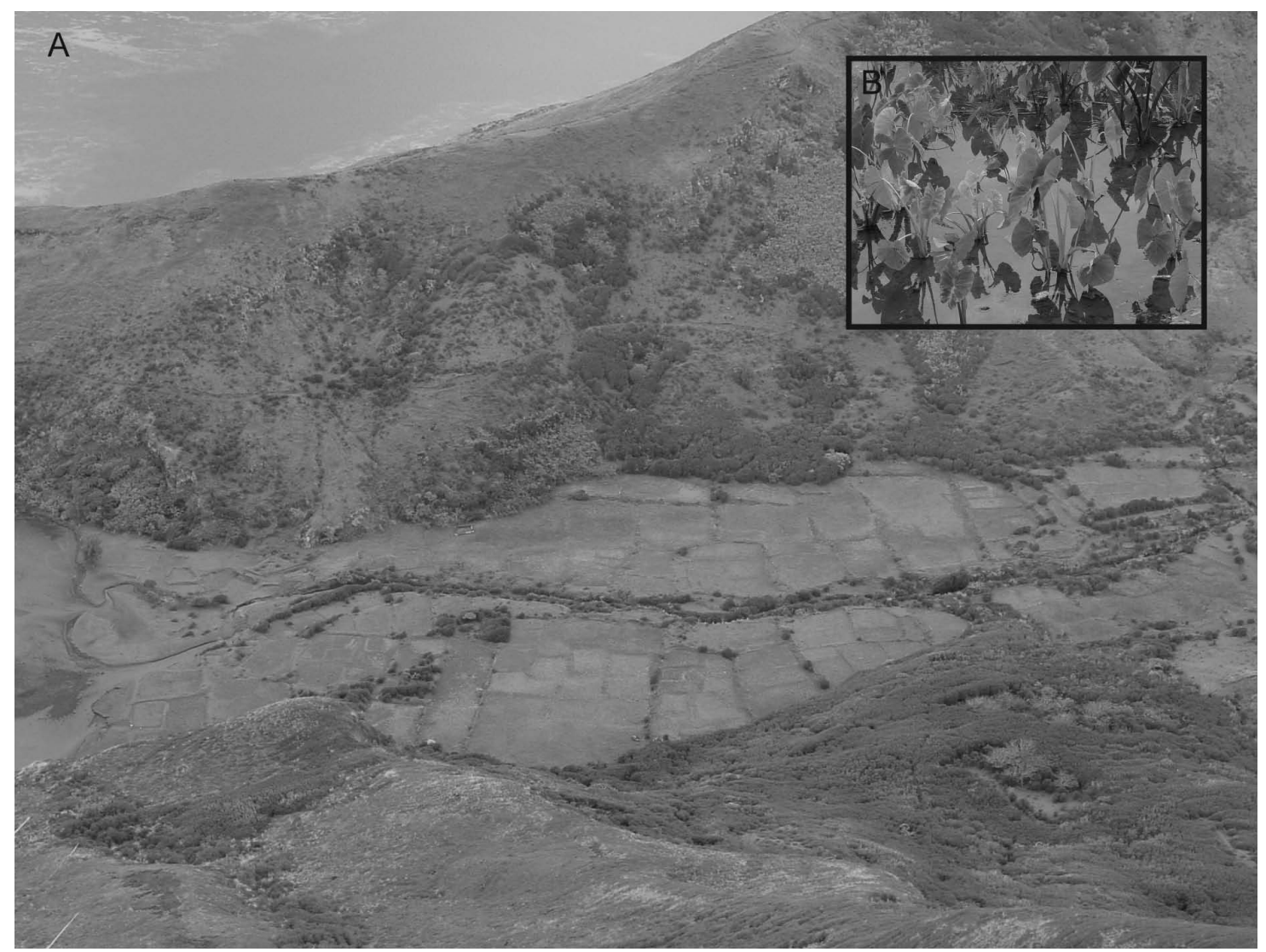

Figure 13.1. A) Modern and remnant pondfields in Akatanui Valley. B) Inset showing Colocasia taro growing in a pondfield. Photograph D.J. Kennett. 
Information regarding Rapan irrigation techniques comes from Hanson (1970). Rapan terraces are rectangular and about 'forty to fifty feet long $[12-15 \mathrm{~m}]$ by twenty to twentyfive feet [6 to $7.5 \mathrm{~m}$ ] wide' (Hanson 1970:70). The terraces are irrigated by narrow ditches. Water from dammed streams runs through notches cut into the curbs surrounding the terraces, descending downhill from the upper to lower levels into the still-water bays surrounding the island. Ideally, each terrace thus is covered with slow-moving water about $5 \mathrm{~cm}$ deep.

Taro can be planted at any time during the year but grows best if planted when conditions are warm, especially January through April. Preparations for taro planting generally begin in September. If there are plans for new terraces or repairs on existing ones the work is done by the men of the household during the last months of the year. To prepare an area for taro irrigation, vegetation is cleared and the surface is levelled. The earth is turned to a depth of about a third of a metre and dirt curbs are built around the terrace, with openings for the ingress and egress of water. The irrigation ditch is excavated next and the terrace is filled with water until the soil is muddy. According to Hanson, 'if the soil is especially good, a terrace can produce a high quality of taro for up to thirty years of continuous cultivation. Rapans feel they have a poor return on labor invested if yields are high only for five or six years' (Hanson 1970:71).

In preparation for the planting season, small peripheral plants are harvested from existing terraces between October and December. Instead of being discarded after the edible corm is broken off, the stalk of the plant is saved. The leaves are removed to reduce the chance that wind will uproot the plant, and the stalk is placed in the terraces. After a month or two, these stalks put down roots and start to grow. In January, these stalks are transplanted in the terraces using the correct spacing for optimal production.

The pondfields are planted by men and women after the New Year, between January and April. Rapans say taro grows best if it is planted during a full or new moon. Taro planting is avoided during the first two weeks of March due to the belief that the corm will mature with a hole running through its centre and is likely to develop corm rot (Hanson 1970:72-73).

Corms and cormels (small, younger corms attached to a fully developed corm) of Colocasia taro are ready for harvest eight months after planting on Rapa. When planted at the correct time of the year, they can be left to grow for up to two years without rotting. Once removed from the pondfield, though, taro spoils in about five days. Both men and women harvest taro throughout the year. Harvesting and transporting taro is considered the hardest part of the process because of the weight burdens and other travel costs associated with retrieving these bulky tubers. Field processing at the harvest site consists of removing the corm from the stalk (see Metcalfe and Barlow 1992; Bettinger et al. 1997). There is little to discard to reduce the weight of these corms for transport. Individuals may have to trek up and down steep ridges carrying $80 \mathrm{lbs}$ (ca. $36 \mathrm{~kg}$ ) or more of taro for household consumption. Occasionally, boats are used to reach fields in more distant watersheds.

Today, women prepare taro for household consumption. Taro corms and cormels must be cooked because in raw form they contain inedible calcium oxalate crystals (Hanson 1970:70). Taro is consumed in a variety of ways once it has been boiled, but usually, it is prepared as a fermented paste called popoi. The preparation of this paste is labour intensive and usually done by younger women in a household. Corms are first boiled and then mashed on the surface of a flat rock until a rounded mass of paste is created $(45-60 \mathrm{~cm}$ in diameter). Water and old popoi is added to aid fermentation and then strenuously kneaded to the desired consistency. The popoi is wrapped in leaf bundles and fermented for one to two days before being consumed by the household (Hanson 1970:73-76) without further preparation. 


\section{Remote sensing of pondfield agricultural systems}

To explore pre- and post-contact ecology and population levels on Rapa, we estimate the maximum extent of pondfield Colocasia taro agriculture using high-resolution IKONOS satellite imagery $(1 \mathrm{~m})$. Modern pondfields are clearly visible in IKONOS imagery and appear as distinctive gray to black areas in the panchromatic image, and dark green in the true colour image (Figure 13.2). Multi-spectral data, specifically false colour infrared, were also used to highlight and define older and more subtle agricultural features (e.g. inactive terraces, wall alignments and old canals). The lateral distribution of these features was used to define the maximum extent of ancient pondfield agricultural systems in all viable lowland environments. Due to erosion, sedimentation, modern development and vegetation obscuring these features, we consider this to be a conservative estimate of the maximum prehistoric agricultural extent. Modern pondfields were only identified in five of the 11 watersheds that contained evidence for more ancient systems, and much more land ( $83.75 \mathrm{ha})$ was under production in the past compared with the present ( 3.73 ha; see discussion and results below). The spatial distribution of modern and prehistoric pondfield agricultural systems varies and is discussed in relation to our efforts to model pre-contact population levels described in the following section.

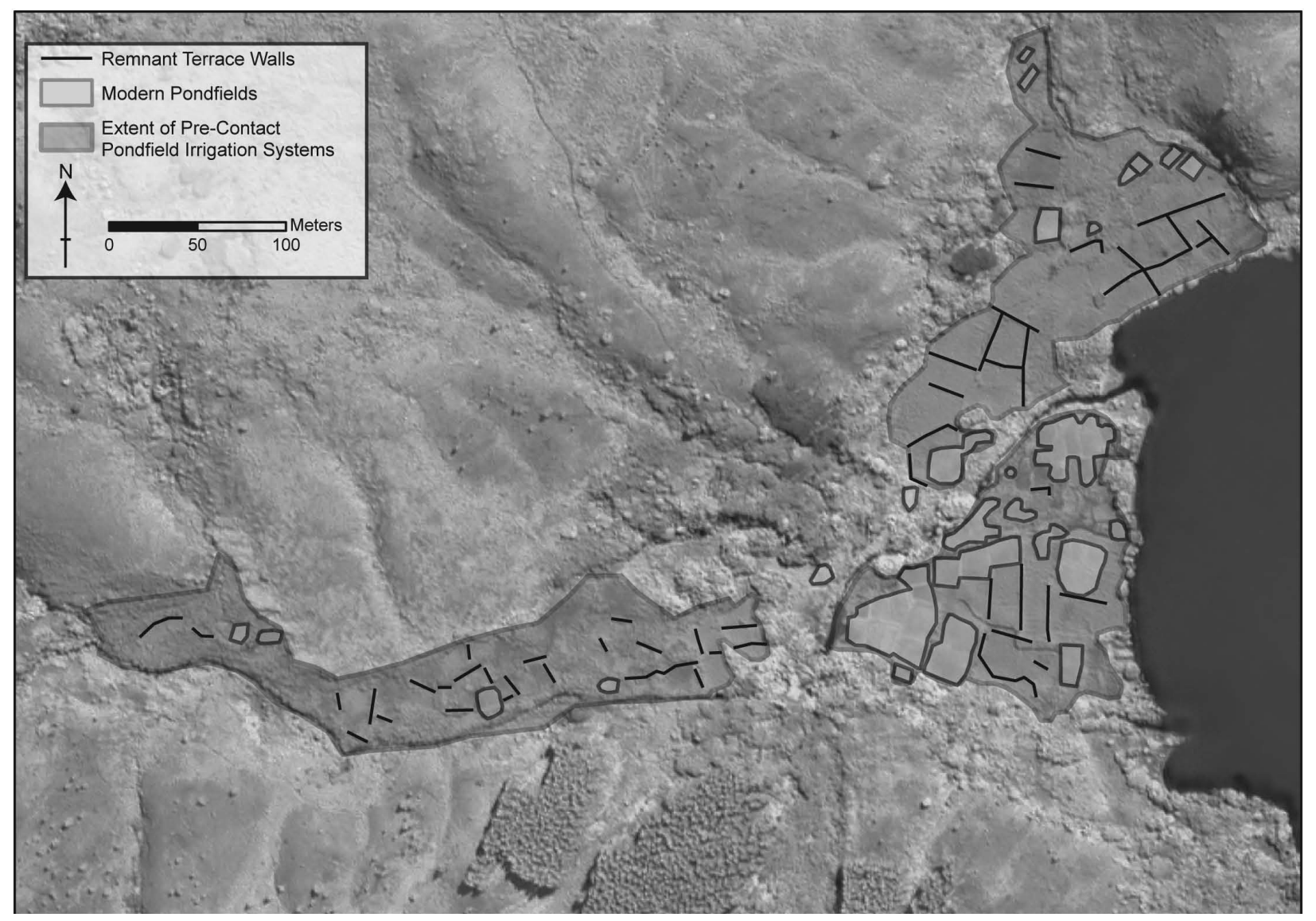

Figure 13.2. Geographic extent of modern and pre-contact pondfield irrigations systems in Angatakuri watershed. 


\section{Modelling population size}

We employ a model that estimates Colocasia taro crop yields and maximum sustainable population sizes based on these estimates, given different levels of diverted production (BaylissSmith 1978, 1980). Based on its successful application in other parts of Oceania (Spriggs 1981; Kirch and Sahlins 1992), we implement a simplified version of this model. Model parameters include: 1) total taro production (in kcals); 2) annual consumption of taro per person (in kcals); 3) annual labor costs; and 4) percentage of the population involved in agricultural production. Population estimates based on the extent of these agricultural systems are determined from this information, given that a portion of the crop may have been diverted away from direct consumption into trade or tribute. Our analysis allows for varying degrees of diversion from $0 \%$ to $70 \%$. The amount of labour (hours per week) associated with different diversion amounts is also determined.

\section{Parameter 1: Total taro production}

We calculate total taro production on Rapa by estimating: 1) the maximum extent of pondfield irrigation systems (in ha); 2) the raw yield of this land (mt/ha/yr); 3) the percentage of the raw yield that is consumable by humans; and 4) the caloric energy provided by taro corms (in kcals). Pondfield agricultural systems were defined in the Rapan lowlands based on the identification of terrace wall alignments and irrigation canals visible in pan-sharpened satellite imagery (See Figure 13.2). Active and inactive pondfields are visible in this imagery and are generally consistent with our observations in the field and Ferdon's independent observations in 1956 (Ferdon 1965). We employ an estimate based on a comparable high-yielding Colocasia taro pondfield agricultural system from the Cook Islands to estimate the annual productivity of 1 ha of land (26.67 mt/ha/year; Manarangi 1984). Geographically and environmentally, this is the closest analogous agricultural system and is considered a better productivity measure on Rapa than the more distant and environmentally different island of Maewo (Vanuate; 35.71 and $58.10 \mathrm{mt} / \mathrm{ha} /$ year; Spriggs 1981, 1984; Kirch and Sahlins 1992). In determining crop yields, we assume that harvests consist of $34 \%$ large corms and $66 \%$ small cormels. Approximately $15 \%$ of large corms and 40\% of cormels consist of inedible peelings (Bayliss-Smith 1980:71-72; Kirch and Sahlins 1992:158). We use 106 kcals to $100 \mathrm{~g}$ of edible taro to convert crop yields, based on previous nutritional studies (Bayliss-Smith 1980:72).

\section{Parameter 2: Annual consumption of taro}

The total energy requirement for humans used in our calculations is $800,000 \mathrm{kcals} /$ person/ year (or ca. $2190 \mathrm{kcal} / \mathrm{day}$ ). This is based on estimates from elsewhere in Oceania (BaylissSmith 1980; Spriggs 1981; Kirch and Sahlins 1992) and is a simplified number that does not take into account variation by age, size, activity level, or the source of the energy. Based on previous research by Stokes (n.d.) and Hanson (1970), along with the limited range of resources available on Rapa (e.g. the island is an inhospitable environment for tropical plants such as coconut, see Chapter 10), we assume that taro comprised $80 \%$ of the pre-contact diet. Based on our own estimates of dietary composition (based on anecdotal evidence collected during archaeological fieldwork between June and August 2002), we argue that taro comprises about $20 \%$ of the contemporary diet. This is due to the importation of a range of supplemental foods from Tahiti. Given these assumptions, we estimate the pre-contact consumption of taro to be 640,000 kcals per person annually (ca. $1750 \mathrm{kcal} /$ day); 160,000 kcals (ca. $435 \mathrm{kcal} /$ day) is estimated for modern populations. 


\section{Parameter 3: Labour costs}

Labour costs are based on analogous modern pondfield agricultural systems in Maewo (Spriggs 1981). The labour costs associated with initial preparation, planting, weeding and harvesting Colocasia taro growing in pondfield irrigation systems is estimated at 4947 person hours/ha/year using stone tools, and 3296 person hours/ha/year for steel tools. Canal excavation and terrace construction is a large initial investment and Rapans expect to get more than seven years of continuous production from a pondfield, and sometimes up to 30 years. To explore changing labour costs associated with continued field use, we use labour estimates for one and 10-year field usage.

\section{Parameter 4: Labour force}

The percentage of the population involved with taro production is more difficult to estimate. On Rapa, men generally prepare pondfields for use and both men and women take part in planting, weeding and harvesting (Hanson 1970). However, we do not know what percentage of men and women took part in these activities in the past and how labour was divided during pre-contact period. Following Kirch and Sahlins (1992), we use a range of estimates for the percentage of people engaged in agricultural activities (80,60, 40, and 30\% of total population).

\section{Population modelling results}

Population estimates using the Bayliss-Smith model are presented in Table 13.1. These estimates assume Colocasia taro yields of 26.67 tonnes ('mt' in Table 1) each year (per hectare) and it is assumed that the entire system was in use prehistorically. Prehistoric population estimates range from 760 to 2534, depending on the amount of taro diverted away from direct consumption. Given our estimates that the current dietary contribution of taro $(20 \%)$ and the area of active cultivation taken from the IKONOS imagery would support 135 to 450 persons depending on the degree of diverted production, this range overlaps with the current population on the island. Also shown in Table 13.1 are the person hours required each week given different assumptions about the fraction of the population engaged in taro production (30-80\%). Individual labour requirements decrease as the percentage of the population involved increases. Bayliss-Smith (1980:80) argued that subsistence activities in the Pacific consume between 10 and 20 hours a week. Estimates above 20 hours per week are identified in parentheses and are thought to be unrealistic.

Two sets of labour estimates are shown in Table 13.1, the first indicating the necessary hours/person/week if pondfields were used for one year and the second showing use amortised over a 10 -year period. These data indicate that individual labour requirements are reduced by more than $50 \%$ with multi-year pondfield use. This is because initial field preparation is a large part of production costs. As an example, the model predicts a prehistoric population of 1774 with a $30 \%$ crop diversion. If $60 \%$ of the population was involved in taro production, then the average producer could expect to work around 7.49 hours each week if fields were used for one year. As a long-term average, weekly labour investment is substantially lower if fields were used continuously over a 10 -year period (3.18 hours per week).

Table 13.2 lists the extent of modern and remnant pondfield agricultural systems in each of the 11 watersheds on Rapa, along with population estimates associated with each based on the Bayliss-Smith model. The spatial distribution of these field systems is shown in Figure 13.3. It is immediately evident that even at their maximum extent, these productive agricultural systems comprised only a small portion of the island's total landmass $(2.21 \%)$ and that these lands were highly circumscribed due to the island's rugged terrain. Modern pondfield agricultural systems 
Table 13.1. Carrying capacity model for Rapa (using $26.67 \mathrm{mt} / \mathrm{ha} / \mathrm{yr}$ as yield).

\begin{tabular}{|c|c|c|c|c|c|c|c|c|c|}
\hline \multirow[b]{3}{*}{ Surplus (\%) } & \multirow[b]{3}{*}{ Population } & \multicolumn{4}{|c|}{ Labor hours/week (one-year field use) } & \multicolumn{4}{|c|}{ Labor hours/week (10-year field use) } \\
\hline & & \multicolumn{4}{|c|}{ Productive $\%$ of population } & \multicolumn{4}{|c|}{ Productive $\%$ of population } \\
\hline & & $80 \%$ & $60 \%$ & $40 \%$ & $30 \%$ & $80 \%$ & $60 \%$ & $40 \%$ & $30 \%$ \\
\hline \multicolumn{10}{|c|}{ Pre-contact taro fields ( $83.75 \mathrm{ha}$ ) } \\
\hline 0 & 2534 & 3.93 & 5.24 & 7.86 & 10.48 & 1.67 & 2.22 & 3.34 & 4.45 \\
\hline 5 & 2407 & 4.14 & 5.52 & 8.27 & 11.03 & 1.76 & 2.34 & 3.51 & 4.68 \\
\hline 10 & 2280 & 4.37 & 5.82 & 8.73 & 11.65 & 1.85 & 2.47 & 3.71 & 4.94 \\
\hline 20 & 2027 & 4.91 & 6.55 & 9.83 & 13.10 & 2.09 & 2.78 & 4.17 & 5.56 \\
\hline 30 & 1774 & 5.62 & 7.49 & 11.23 & 14.97 & 2.38 & 3.18 & 4.77 & 6.36 \\
\hline 40 & 1520 & 6.55 & 8.73 & 13.10 & 17.47 & 2.78 & 3.71 & 5.56 & 7.42 \\
\hline 50 & 1267 & 7.86 & 10.48 & 15.72 & $(20.96)$ & 3.34 & 4.45 & 6.67 & 8.90 \\
\hline 60 & 1014 & 9.83 & 13.10 & 19.65 & $(26.20)$ & 4.17 & 5.56 & 8.34 & 11.12 \\
\hline 70 & 760 & 13.10 & 17.47 & $(26.20)$ & (34.94) & 5.56 & 7.42 & 11.12 & 14.83 \\
\hline \multicolumn{10}{|c|}{ Modern taro fields ( $3.73 \mathrm{ha}$ ) } \\
\hline 0 & 450 & 0.65 & 0.87 & 1.31 & 1.75 & 0.39 & 0.52 & 0.77 & 1.03 \\
\hline 5 & 428 & 0.69 & 0.92 & 1.38 & 1.84 & 0.41 & 0.54 & 0.81 & 1.08 \\
\hline 10 & 405 & 0.73 & 0.97 & 1.45 & 1.94 & 0.43 & 0.57 & 0.86 & 1.14 \\
\hline 20 & 360 & 0.82 & 1.09 & 1.64 & 2.18 & 0.48 & 0.64 & 0.97 & 1.29 \\
\hline 30 & 315 & 0.94 & 1.25 & 1.87 & 2.49 & 0.55 & 0.74 & 1.10 & 1.47 \\
\hline 40 & 270 & 1.09 & 1.45 & 2.18 & 2.91 & 0.64 & 0.86 & 1.29 & 1.72 \\
\hline 50 & 225 & 1.31 & 1.75 & 2.62 & 3.49 & 0.77 & 1.03 & 1.55 & 2.06 \\
\hline 60 & 180 & 1.64 & 2.18 & 3.27 & 4.36 & 0.97 & 1.29 & 1.93 & 2.58 \\
\hline 70 & 135 & 2.18 & 2.91 & 4.36 & 5.82 & 1.29 & 1.72 & 2.58 & 3.43 \\
\hline
\end{tabular}

are even more restricted, occurring in only seven of the 11 major drainages on the island. The extensive lowlands surrounding Ha' urei Bay were divided into three areas for analytical purposes, but in total comprise $60.56 \%$ (2.25 ha) of the lands currently under production. Large pondfield agricultural systems are also in use in Angatakuri/Angatakuri Naku (26.02\%) and Iri (13.26\%) drainages, both located in the southern half of the island, with smaller systems positioned in the Pariati drainage $(0.16 \%)$ to the north. The model-derived population estimate based on the modern extent of pondfield agricultural systems is 450 individuals. This estimate is based on the assumption that there is little taro diverted away from direct human consumption due to heavy subsidies from the French Polynesian government.

Pondfield agricultural systems were more extensive in the past. Remnant pondfield systems were identified in all of the major drainages examined $(n=11)$ and their overall extent $(83.75$ ha) was ca. 20 times larger than the modern systems. These abandoned and now fragmentary systems were most extensive around the periphery of Ha'urei Bay (41.12 ha, 49.10\%) and were particularly concentrated in the lowlands along its northwestern shore (30.94\%; Figure 13.4). Large pondfield systems were also located in Iri (11.35 ha) and Angatakuri (5.38 ha) drainages to the south, and Akatanui (6.48 ha), Agaira ( 4.85 ha) and Pariati ( 4.44 ha) drainages to the north (see Figure 13.3). Smaller systems were also identified in several drainages in the north 
(Akananu, Akatamiro, Anarua and Tupuai). These data point to much higher and more widely distributed populations in the past. We conservatively estimate an island population of 2027 based on the maximum identifiable extent of pondfield systems on the island (Table 13.1). This estimate is based on an $80 \%$ dietary contribution of taro from pondfield systems and does not include other dry farming systems (e.g. terraces) of unknown extent and importance. This estimate includes a diversion of $20 \%$ of the production, which we argue to be reasonable given the need to protect against drought, lower crop yields on a year to year basis, and food losses due to war. Taro production is spatially distributed almost evenly throughout the island, with the highest pre-contact production systems occurring in the central to northwest section of the island, followed by the southern section of the island, with the east to northeastern areas of the island a close third.

Table 13.2. Carrying capacity by watershed.

\begin{tabular}{|c|c|c|c|c|}
\hline Watershed & Pondfield area (h) & $\begin{array}{l}\text { Percentage of total } \\
\text { pondfield area }\end{array}$ & Surplus (\%) & Population \\
\hline \multicolumn{5}{|c|}{ Pre-contact taro extents } \\
\hline Agaira & 4.85 & $5.79 \%$ & 20 & 117 \\
\hline Akananu & 2.95 & $3.52 \%$ & 20 & 71 \\
\hline Akatamiro & 1.07 & $1.28 \%$ & 20 & 26 \\
\hline Akatanui & 6.48 & $7.74 \%$ & 20 & 157 \\
\hline Anarua & 1.20 & $1.44 \%$ & 20 & 29 \\
\hline Angatakuri & 5.38 & $6.42 \%$ & 20 & 130 \\
\hline Angatakuri Nako & 2.18 & $2.60 \%$ & 20 & 53 \\
\hline Ha'urei East & 6.67 & $7.96 \%$ & 20 & 162 \\
\hline Ha'urei South & 8.53 & $10.19 \%$ & 20 & 206 \\
\hline Ha'urei West & 25.92 & $30.94 \%$ & 20 & 627 \\
\hline Iri & 11.35 & $13.55 \%$ & 20 & 275 \\
\hline Pariati & 4.44 & $5.30 \%$ & 20 & 108 \\
\hline Tupuai & 2.73 & $3.25 \%$ & 20 & 66 \\
\hline Total & 83.75 & $100.00 \%$ & & 2027 \\
\hline \multicolumn{5}{|c|}{ Modern taro fields } \\
\hline Angatakuri & 0.79 & $21.25 \%$ & 0 & 96 \\
\hline Angatakuri Nako & 0.18 & $4.77 \%$ & 0 & 23 \\
\hline Ha'urei East & 0.78 & $21.04 \%$ & 0 & 94 \\
\hline Ha'urei South & 0.36 & $9.66 \%$ & 0 & 44 \\
\hline Ha'urei West & 1.11 & $29.86 \%$ & 0 & 134 \\
\hline Iri & 0.49 & $13.26 \%$ & 0 & 59 \\
\hline Pariati & 0.01 & $0.16 \%$ & 0 & 1 \\
\hline Total & 3.73 & $100.00 \%$ & & 450 \\
\hline
\end{tabular}




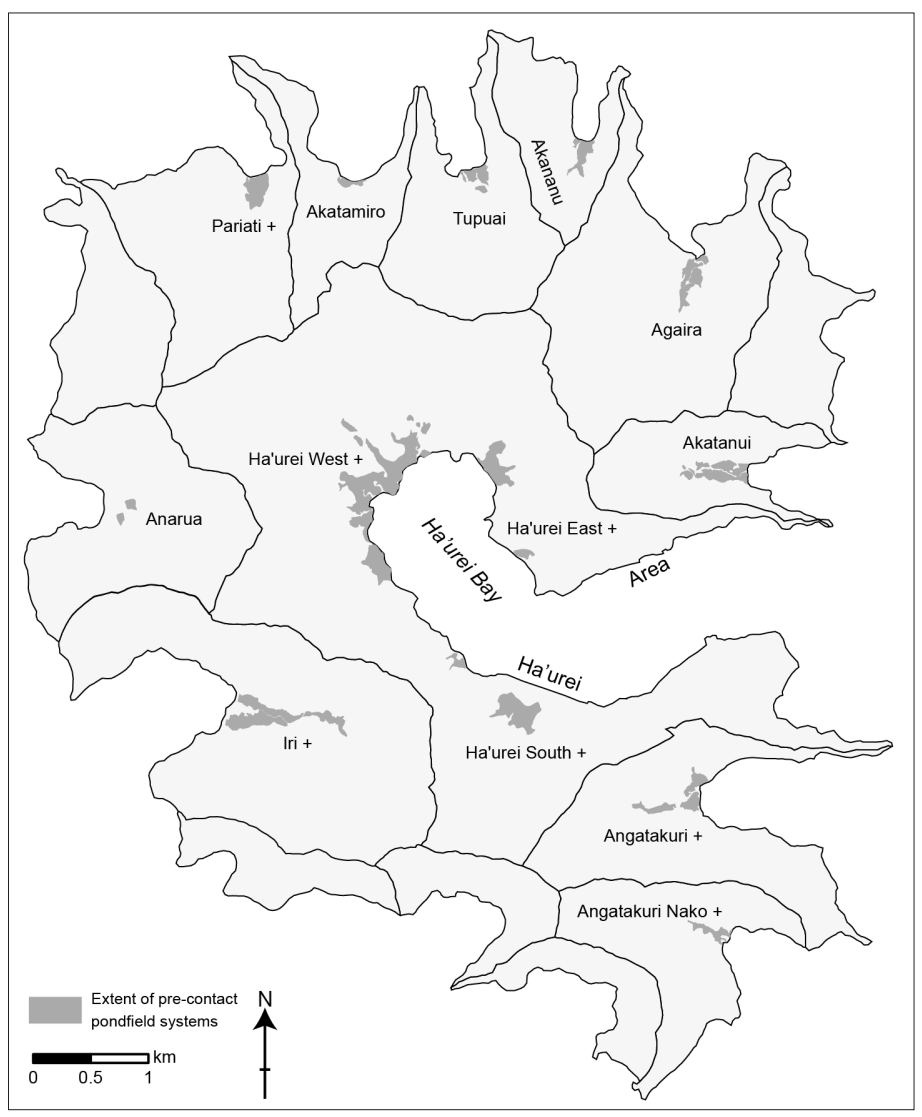

Figure 13.3. Spatial extent of precontact pondfield systems for each watershed (+ denotes watersheds with modern pondfield systems).

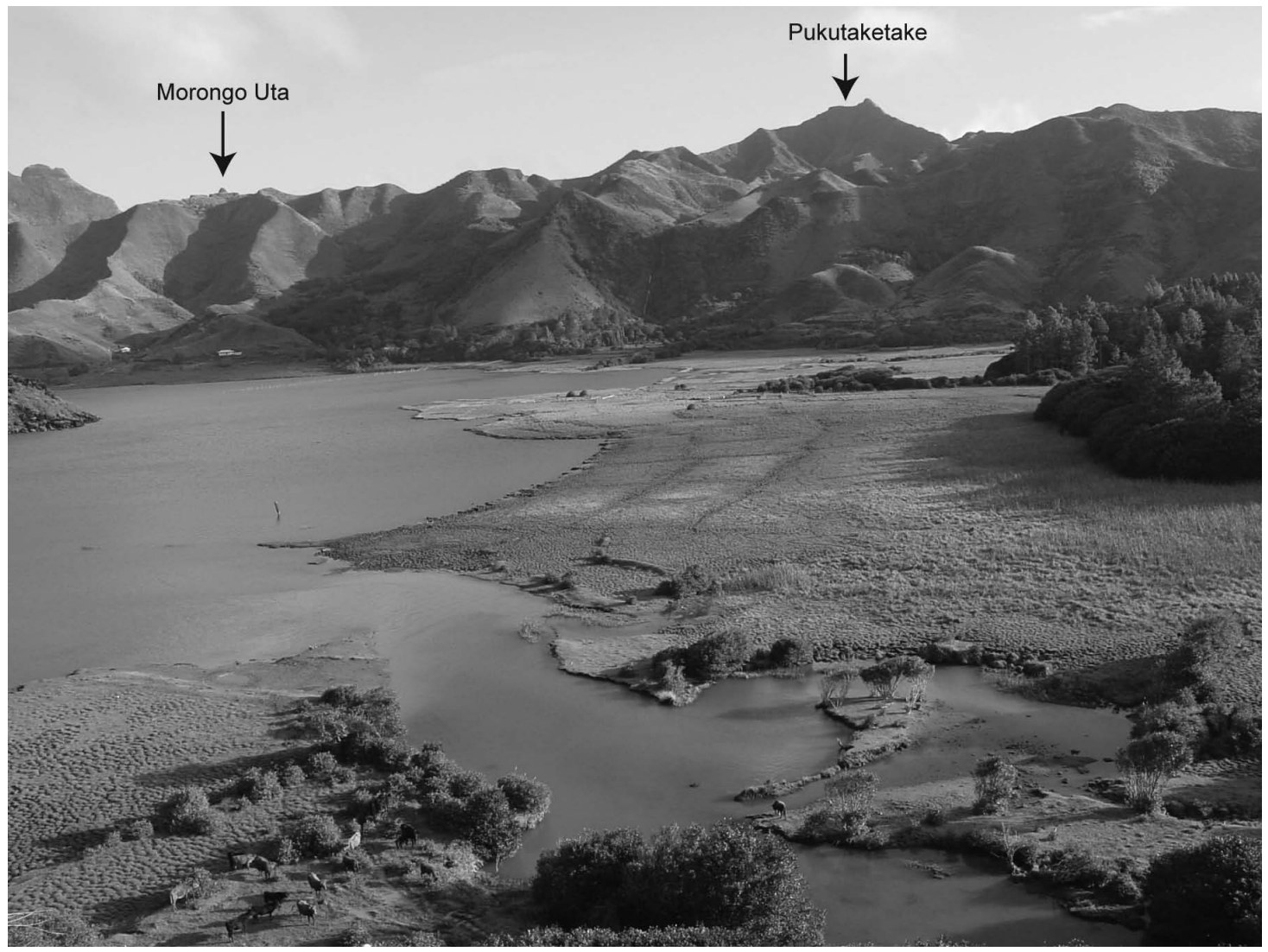

Figure 13.4. Inactive remnant pondfields on the north shore of Ha'urei Bay. Note the remnants of the prehistoric fortified communities of Morongo Uta and Pukutaketake. Photograph D.J. Kennett. 


\section{Discussion and conclusion}

Since European contact, the population of Rapa has plummeted from an estimated high of 2000 in 1826 to a low of 120 in 1867 (McArthur 1967:307). Within the past 140 years, the population has slowly increased. It stands at 497 , according to the latest official census taken in 2002 (http://www.polynesie-francaise.gouv.fr/hc/iles-australes/dossiers.asp\#rapa). Our model prediction of 450 persons - under the assumptions that 3.72 hectares are in production and that taro is $20 \%$ of the diet - is quite close to the contemporary census result. Today, Rapan people rely on supplies from Tahiti, imports from abroad and introduced domesticated animals, and this has decreased the importance of taro and taro-based products in the diet. For these reasons, in the present it is more difficult to determine population solely from taro production. Inhabitants of Rapa do not have to depend on taro agriculture for a majority of their diet and the time that would be involved in more intensive agriculture is spent on introduced cash crops such as coffee. Further research on the modern populations is needed to account for all the energy sources that are available and their relative contribution to the diet.

Many of these complexities were absent in pre-contact time due to the heavy subsistence dependence on taro and fish and the lack of imported bulk commodities. This simplification of the pre-contact diet makes it easier to calculate the maximum sustainable population sizes based on taro production. With a diversion of $20 \%$, the model results in a maximum sustainable population of 2027 individuals. This result is supported by early estimates from European sources within the first 30 years of contact, which put the population between 1500 and 2000 individuals. When Vancouver first encountered the island of Rapa in 1791, his ship was confronted at sea by "about thirty" canoes that contained "on a moderate computation, three hundred men, all adult and apparently none exceeding a middle-age; so that the total number of inhabitants on the island can hardly be estimated at less than fifteen hundred" (Vancouver 1801). Stokes (n.d.) thought this number too low, reasoning that Vancouver was probably only met by inhabitants from the north and west of the island. In 1826, John Davies visited Rapa for a second time and estimated the population to be around 2000, even though there had been 'much sickness and death in the island' since his first visit earlier in the year (McArthur 1967:307).

More recently, Stokes (n.d.) estimated the pre-contact population by surveying the fortified and unfortified terraced mountain sites and calculated that if all the sites were occupied at the same time they could house about 3000 inhabitants (see also Anderson, Chapter 2). If Stokes' estimate is closer to the number of people living on Rapa then - with respect to our model estimates - production diversion must have been lower, yield per hectare must have been higher, and/or more land not evident in our satellite imagery was dedicated to taro production. Ferdon (1965) mentions taro terraces further up the valleys of several watersheds. These terraces may have been for dry taro agriculture, but they cannot be seen on the satellite imagery and were not added to the maximum pre-contact extent calculations. It is not known for certain whether these were domestic terraces, similar to the ones Stokes surveyed, dry taro terraces, or a combination of both.

Through the use of the Bayliss-Smith model, we have shown that within the circumscribed environment of Rapa and the limited amount of arable land, the island could have supported population levels in line with or above early European estimates. The use of satellite imagery and the Bayliss-Smith model (Bayliss-Smith 1978, 1980) allows for a cost-effective approach to reconstructing agricultural systems and population levels on Rapa and could readily be used on other islands in the Pacific. Additional ethnographic fieldwork is also needed to help constrain 
model parameters, and archaeological work to establish the extent of remnant pondfields and other agricultural features (e.g. dry terraces, irrigation canals).

The population estimates presented in this paper are intriguing given the known development and expansion of fortified hilltop communities on the island (Kennett et al. 2006). These communities were strategically located on the highest peaks along the ridge system dividing the primary watersheds on the island. The distribution of these communities suggests that they demarcated territories. The earliest fortifications (Morongo Uta and Ruatara) were established 100 years after the island was colonised (ca. AD 1300-1400, see Chapter 11) and were positioned near the most suitable lands for pondfield agriculture. The number of fortified communities proliferated after $\mathrm{AD} 1700$, just before the first recorded European contact in AD 1791. Population expansion and community fissioning to fortified locations parallels the expansion of pondfield agricultural systems on the island. We suggest that the expansion of pondfield agricultural systems increased the value of land that was highly circumscribed and defensible. This stimulated territorial disputes that were likely one of several interacting contextual variables favouring increased inter-group aggression and greater investment in defence, as has been argued for the Northern Channel Islands of southern California (Kennett et al. 2009; Winterhalder et al. 2010).

\section{References}

Bayliss-Smith, T.P. 1978. Maximum populations and standard populations: The carrying capacity question. In: Green, D. Haselgrove, C. and Spriggs M. (eds), Social Organisation and Settlement, pp. 129-51. Part 1. BAR International Series (supplementary) 47. Oxford.

Bayliss-Smith, T.P. 1980. Population pressure, resources, and welfare: Towards a more realistic measure of carrying capacity. In: Brookfield, H.C. (ed), Population-environment Relations in Tropical Islands: The Case of Eastern Fiji, pp. 61-93. M.A.B. Technical Notes 13. Paris.

Bellwood, P.S. 1975. Man's Conquest of the Pacific. Collins, London.

Bettinger, R.L., Malhi, R. and McCarthy, H. 1997. Central place models of acorn and mussel processing. Journal of Archaeological Science 24:887-899.

Cable, W.J. 1984. The spread of taro (Colocasia sp.) in the Pacific. In: Chandra S. (ed), Edible Aroids, pp. 28-33. Clarendon Press, Oxford.

Dyson-Hudson, R. and Smith, E.A. 1978. Human territoriality: An ecological reassessment. American Anthropologist 80:21-41.

Ferdon, E.N. Jr. 1965. A reconnaissance survey of three fortified hilltop villages. In: Heyerdahl, T. and Ferdon, E.N. (eds), Reports of the Norwegian Archaeological Expedition to Easter Island and the East Pacific, Volume 2, miscellaneous papers. Monographs of the School of American Research.

Golson, J. 1990. Kuk and the development of agriculture in New Guinea: Retrospection and introspection. In: Yen, D.E. and Mummery, J.M.J. (eds), Pacific Production Systems: Approaches to Economic Prehistory pp. 139-47. Australia National University, Canberra.

Hanson, F.A. 1970. Rapan Lifeways: Society and History on a Polynesian Island. Little, Brown and Company Ltd, Boston.

Haut-commissariat de la Polynésie française: Subdivision administrative des les Australes: Communes. http://www.polynesie-francaise.gouv.fr/hc/iles-australes/dossiers.asp. Accessed on 20 November 2006.

Kennett, D.J., Anderson, A.J., Prebble, M., Conte, E. and Southon, J. 2006a. The Ideal Free Distribution, Food Production, and the Colonization of Oceania. In: Kennett, D.J. and 
Winterhalder, B. (eds), Behavioral Ecology and the Transition to Agriculture, pp. 265-288. University of California Press, Berkeley.

Kennett, D.J., Anderson, A. and Winterhalder, B. 2006b. Prehistoric human impacts on Rapa, French Polynesia. Antiquity 80:340-54.

Kennett, D.J., Winterhalder, B., Bartruff, J. and Erlandson, J.M. 2009. An ecological model for the emergence of institutionalized social hierarchies on California's Northern Channel islands. In: Shennan, S. (ed), Pattern and Process in Cultural Evolution, pp. 297-314. University of California Press, Berkeley.

Kirch, P.V. 2000. On the road of the winds: an archaeological history of the Pacific Islands before European contact. University of California Press, Berkeley.

Kirch, P.V. and Sahlins, M. 1992. Anahulu: The Anthropology of History in the Kingdom of Hawaii, Volume Two: The Archaeology of History. University of Chicago Press, Chicago.

Loy, T., Spriggs, M. and Wickler, S. 1992. Direct evidence for human use of plants 28,000 years ago: starch residues on stone artefacts from northern Solomon Islands. Antiquity 66:898-912.

Manarangi, A. 1984. Important taro varieties in the Cook Islands. In: Chandra, S. (ed), Edible Aroids, pp. 24-27. Clarendon Press, Oxford.

McArthur, N. 1967. Island Populations of the Pacific. The Australian National University Press, Canberra.

Metcalfe, M.D. and Barlow, K.R. 1992. A model for exploring the optimal trade-off between field processing and transport. American Anthropologist 94(2):340-356.

Spriggs, M. 1981. Vegetable Kingdoms: Taro Irrigation and Pacific Prehistory. Unpublished PhD dissertation. The Australian National University, Canberra.

Spriggs, M. 1984. Taro irrigation methods in the Pacific. In: Chandra, S. (ed), Edible Aroids, pp. 123-35. Clarendon Press, Oxford.

Spriggs, M. 1988. The Past, Present and Future of Traditional Taro Irrigation in the Pacific: An Example of Traditional Ecological Knowledge. SPREP Occasional Paper Series 3. South Pacific Commission, Noumea.

Stokes, J.F.G. n.d. Ethnology of Rapa. Manuscript on file in the Bernice P. Bishop Museum, Honolulu.

Vancouver, G. and Vancouver, J. 1801. A voyage of discovery to the North Pacific ocean, and round the world. J. Stockdale, London.

Winterhalder, B., Kennett, D.J., Grote, M.N. and Bartruff, J. 2010. Ideal Free Settlement of California's Northern Channel Islands. Journal of Anthropological Archaeology 29:469-490.

Yen, D.E. 1991. Polynesian cultigens and cultivars: The question of origin. In: Cox, P.A. and Banack, S.A. (eds), Islands, Plants, and Polynesians, pp. 67-98. Dioscorides Press, Portland, Oregon. 